\section{THE GEOLOGY OF THE TERRESTRIAL PLANETS}

M.H. Carr (ed.), R.S. Saunders, R.G. Strom and D.E. Wilhelms

NASA SP-469, 1984, 317p, $\$ 16.00$ (US)

Since the launch of Mariner 2 toward Venus in 1962, a great store of information on the various planetary bodies has been gathered by an assortment of earth-based instruments, planetary fly-by missions, orbiting spacecraft, probes, and landers. For the innermost five planets (including Earth's moon) of the solar system, termed the 'terrestrial planets' because of their silicate composition, these observations have permitted reasonable models of

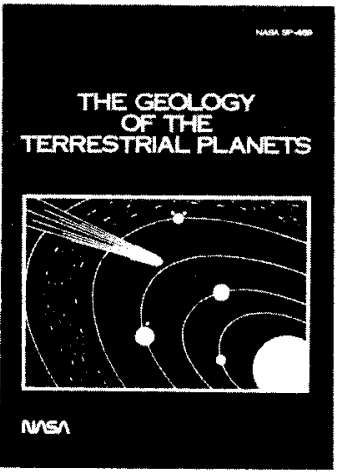
advanced. The Geology of the Terrestrial Planets represents an ambitious attempt to present the geologic histories of Mercury, Venus, Earth, Mars, and the Moon.

The book is organized into eight chapters. A brief introductory chapter presents an overview of solar system exploration and is followed by an equally brief, but important, chapter summarizing available information on asteroids and comets and their relevance to understanding the early solar system and formation of the planets. Each of the terrestrial planets is discussed independently in the next five chapters, with no apparent effort to maintain continuity of format or content from one chapter or planet to the next. In general, these chapters are informative and well written. Strom's chapter on Mercury, Wilhelms' on the Moon, and the Mars chapter by Carr are particularly interesting. Each is an in-depth, relatively complete treatment of the current state of geological knowledge, and each illustrates the rich diversity of data, analytical techniques and surface processes that typifies planetary geology.

The chapter on Venus by Saunders and Carr is already somewhat outdated. This, however, is more an expression of the dynamic nature of planetary exploration than a fault of the authors. In the last three years, the Soviet Venera 15 and 16 radar orbiters, together with further analyses of earth-based and Pioneer Venus data have significantly advanced the current perception of the geology of this planet.

The treatment of the geology of the Earth is disappointing. Clearly, this cannot be adequately summarized in the 27 pages given it in this book. While strongly focusing on internal structure and detailing the historical development of plate tectonies, the author misses a prime opportunity to discuss the importance on Earth of the major surface processes observed on the other planets such as fluvial and aeolian activity, volcanism and impact cratering. Indeed, these topics are not mentioned at all in this chapter, perhaps because of Carr's opinion that "geomorphology plays a relatively minor role in terrestrial geology." Discussions of the effects of planetary variables on the tectonic evolution of Earth, and the role of planetary exploration and remote sensing in terrestrial geology would have made excellent contributions to the book.

The last chapter is a brief (4 page) and somewhat repetitive summary, which presents a comparative approach to planetary evolution. This is nonetheless an important synthesis of the preceding chapters, and treats planetary evolution in terms of four major processes: impact cratering, volcanism, tectonism, and weathering. The book would have been stronger if more emphasis had been placed on these types of comparisons, providing more detailed analysis of the processes presented and including others, such as, differentiation of planetary crusts and mass wasting. Finally, there is a series of maps of the terrestrial planets, without captions or explanation. The gray-code legend for the venus topographic map was apparently deleted.

The book is copiously referenced and well illustrated. Figures include some colour illustrations; all are adequate in size and located within the text. While a few typographical errors are evident, technical and scientific editing is acceptable. The Table of Contents and Index are well organized, clear and complete.

It is difficult to determine a suitable readership for this book. Some discussions, for example of the inferences made from cratering statistics and morphometry, are highly technical and would overwhelm the uninitiated reader; yet other portions of the book are laden with introductory discussions, historical perspectives, and fundamentals that a more advanced reader would find tedious and unnecessary. This lack of purpose and consistency is perhaps the most detracting aspect of the book. Nevertheless, The Geology of the Terrestrial Planets is an important contribution to the growing number of books documenting planetary geology.

V.L. Sharpton Ottawa, Canada

\section{NATURAL ZEOLITES}

by Glauco Gottardi and Ermanno Galli

Springer-Verlag, Berlin, Heidelberg, New York, Tokyo, 1985, 409p., \$59.00 (US)

The literature on zeolites is vast, their mineralogy is complex, and the number of scientists in a wide range of disciplines who encounter zeolites in the course of their work is also very large. An easily accessible reference book on natural zeolites with appropriate comparisons with synthetic zeolites has been a clear need. Professors Gottardi and Galli of the University of Modena, Italy, two long-term and prolific workers in the field, have now filled this gap. This is a work that will be

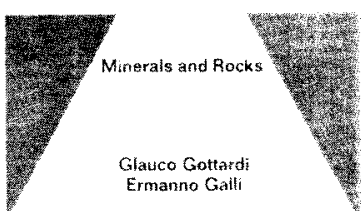

Natural Zeolites indispensible both for specialists and for the many others who from time to time need information on natural zeolites. But as the authors rightly point out, mineralogy is an interdisciplinary field and it is almost impossible to meet every requirement.

A preliminary chapter describes the various structural frameworks of zeolites, arranging these into six main groups. In subsequent chapters, 46 species and varieties are considered under the headings: history and nomenclature, crystallography, chemistry and synthesis, optical and other physical properties, thermal and other physico-chemical properties (including TG, DTG, and DTA thermal curves), 
occurrence and genesis, and in some cases, uses and applications. It is unfortunate that a subcommittee of the International Vineralogical Association that is currently working on zeolite nomenclature had not made its report at the time the book was written. It is thus possible that there may in future be some changes in recommended nomenclature in controversial areas, such as in the role of framework cations, extra-framework cations, and order-disorder relationships in the definition of valid species as distinct from varieties.

Indexed X-ray powder diffraction patterns are given in an appendix. Like the thermal curves these have in most cases been specially recorded and interpreted by the authors. Another appendix contains infra-red spectra of the fibrous zeolites. A special strength of the work is the inclusion of many beautiful SEM photos showing typical habits of many of the species described. The bibliography contains about 1,000 references and innumerable occurrences of common zeolites, and where possible all known occurrences of rarer zeolites are mentioned. The literature on zeolites is so large however - and so on-going - that it is inevitable that selection has been required and some significant items have been omitted.

One interesting recently described occurrence that missed inclusion is of yugawaralite and surprisingly abundant epistilbite in what is evidently a fossil hydrothermal system affecting are volcanics and volcaniclastic sediments of Permian age, described by B.F. Houghton in 1982 in the New \%ealand Journal of Geology and Geophysies (v. 25, p. 1-19). An older classic that has been omitted, and surprisingly does not appear to have been the subject of systematic modern study, is the occurrence of various zeolites in the masonry of Roman hot water baths (e.g. A. Daubrée, 1879, Etudes Synthetiques de Géologie Experimentale, Paris).

The authors appear to be less confident in their handling of geological and petrological aspects, including phase equilibria, than in crystallographic matters. Thus the "prehnite - pumpellyite stage," which they attribute to the zeolite "metamorphic" facies, is not part of the this facies as defined in the 1959 paper they refer to. In fact it formed the basis of separate facies defined in later papers. Again, the statement (p. 87) that "Coombs et al. (1959) were able to state that wairakite is stable from about 370 to $450^{\circ}$ and up to 4 kbars" is quite incorrect. In fact we preferred to give explicit reasons for suggesting that wairakite is not stable at temperatures as high as this. Unfortunately this is not the only place where Gottardi and Galli confuse fields of synthesis with stability fields and misinterpret or overlook items referred to in the literature on zeolite synthesis and genesis.

Representative chemical analyses are given for each zeolite species and accepted variety, and its range of variability is discussed. I would suggest that in any revised edition of the book, more use could advantageously be made of ternary plots to show this variability more comprehensively. Further, the attributing of a single "stoichiometric" or "schematic" formula to each mineral species or variety gives at best an approximation to what the composition of an actual zeolite may be, and at worst can be grossly misleading both for framework atoms and for extraframework cations. In fact this all-too-common practice is one that panders to our perceptions of what is simple or ideal, rather than to the realities of nature.

Interesting notes are given on the uses of some zeolites, enough to whet the appetite for more. In these days of increasing awareness of environmental hazards it is a pity that the other side of the coin was not also mentioned. Thus fibres of sedimentary erionite were heavily implicated by
P.C. Elmes in 1980 as a possible cause of the extraordinary incidence of mesothelioma in the village of Karain in Turkey (Journal of the Geological Society, v. 137, p. 525-535).

In spite of these eritical comments, the authors are to be congratulated on what they have achieved. Users should be prepared to check on original sources, but then that is always the case for serious research. The authors have brought together a tremendous amount of material, which, viewed with normal discretion, will provide essential reading and references for zeolite workers for many years to come.

D.S. Coombs

Dunedin, New Zealand

\section{HYPERSALINE ECOSYSTEMS - THE GAVISH SABKHA}

G.M. Friedman and W.E. Krumbein (eds.)

Springer-Verlag, Germany, 1985, $\$ 98$ (US)

This compilation of papers on the ecology of marginal marine supra-tidal environments of arid and semi-arid regions is dedicated to the memory of Eliezer Gavish. The majority of the contributions by 32 sci- $^{-}$ entists from Israel, The Netherlands, France, West Germany and the U.S.A. deal with the Gavish Sabkha of the northern Gulf of Aqaba (Elat). Following a rather effusive introduction, the book discusses the framework of hyper-saline environments with special reference to the northern Red Sea, and presents a somewhat repetitive and unintegrated case study of the Gavish Sabkha, and a concise account of the paleoecology of these special environments and their economic aspects. Although many of the contributions relate specifically to the Gavish Sabkha, it is not precisely clear where this is situated until chapter 9 , and much of the book relates to other areas with hypersaline environments.

This multidisciplinary account allows readers from various backgrounds to gain a well balanced view of process and result in hypersaline environments. Sedimentologists will be especially interested in the second section, which includes a review by B.H. Purser of the general geological setting and sedimentary mechanisms that produce coastal sabkhas throughout the world. The geological and sedimentological framework of the Gulf of Elat is described by G.M Friedman. There is a well-balanced range of subject matter stretching from traditional clear descriptions of the sabkha to a highly technical, biochemical and mathematical approach to its investigation.

The early chapters describe the zonation of colonizing fauna and flora, with correlations to parameters such as water potential, oxidation/reduction potential, and light availability. The importance of the protective microbial slime layers in maintaining some of the unique features of the sabkha environment is stressed by G. Gerdes, W.E. Krumbein and E. Holtkamp. Its presence as a barrier to quick gas diffusion is suggested as the reason for the coexistence of hydrogen sulphide and oxygen. 
There is a fascinating study of some very unusual bacteria that are highly adapted to the extreme conditions of the sabkha. Mechanisms for tolerating these conditions are discussed by M. Kessel, Y. Cohen and A.E. Walsby, and the role of photoactive pigments in the workings of a lightdriven proton-pump are described by $W$. Stoeckenius, D. Bivin and $K$. MeGinnis. Although some familiarity with more "normal" prokaryotic metabolic processes would be an advantage to the reader, the explanations are clear and a lack of such knowledge should not be a severe handicap.

Later chapters deal with biochemical analyses of the microbiota of the sabkha. These methods are in their infancy, and a publication such as this is a valuable indicator of the huge potential these techniques have for studying environments where traditional microbiological methods cannot be used. Such techniques are also invaluable in providing information on the changes in the biogeochemistry of the sabkha sediments before and after the sheetfloods of 1979-80. The fact that the rigid structure of wellestablished microbial mats has been destroyed is reflected in changes in the characteristic lipid and sugar fingerprints identified by gas chromatography and mass spectrometry (J.W. de Leeuw and others) and by pyrolysis mass spectrometry (J.J. Boon et al.). The decomposition of some of the components such as the protective slime layers is inferred from these biochemical analyses; such knowledge has important implications for other paleointerpretations.

The book also deals with environmental conditions leading to selective colonization of the sabkha and the biogeochemistry resulting from such zonation. Accumulation of metabolic wastes such as hydrogen sulphide is an obvious example, but the concentration of trace metals is of more economic interest, being attributed, at least in part, to the microflora of the region. This is demonstrated by the fact that trace metal concentrations in these sediments are lower than in nearby marine environments; the microbial mats, however, are enriched in trace metals, as shown by W.B. Lyons and H.E Gaudette. These results are particularly pertinent, for base metal mineralization is commonly associated with evaporites, though its precise origin has still to be discovered.

A few contributions deal with stable isotopes. Values of $\delta^{34} \mathrm{~S}$ are used to determine whether sulphates were precipitated from brines of marine or non-marine origin. The importance of this approach is highlighted by the carbon isotope study by $M$. Schidlowski and others of microbial mats from the Gavish Sabkha and Solar Lake, which shows the $\delta^{13} \mathrm{C}$ values of the mats to be very high as a consequence of extraordinary enrichment in the heavier $13_{\mathrm{C}}$ isotope compared to "average organic matter." The low solubility of $\mathrm{CO}_{2}$ in hypersaline water causes photosynthetic reactions taking place in the mats to use ${ }^{13} \mathrm{CO}_{2}$ as well as the preferred ${ }^{12} \mathrm{CO}_{2}$ as carbon dioxide is in short supply. By contrast in other environments photosynthetic reactions mostly use ${ }^{12} \mathrm{CO}_{2}$.

Phanerozoic stromatolites have similar values but those of Proterozoic age have average $\delta^{13} \mathrm{C}$ values for organic matter. This difference is explained by the evolution of grazing and burrowing animals at the beginning of the Phanerozoic, causing the destruction of microbial mats in all environments except those too hostile for herbivores. Schidlowski and his colleagues show how $\delta^{13} \mathrm{C}$ and ${ }_{0}^{16} \mathrm{O}$ values are calculated, thus enabling the reader to understand the results without any prior knowledge of isotope geochemistry.

The economic importance of sabkha systems in relation to evaporite deposits, heavy metal and phosphate deposits, salt-water agriculture and biotechnology is effectively summarized by W.E. Krumbein. The study of modern microbial mats may produce a better understanding of ancient stromatolites for according to A.H. Knoll the microbial mats that formed them appear to have evolved very little since the Proterozoic. In the same context some remarkable observations from Baja California by G. Gavish and others show how the wind can move whole microbial mats over the ground producing "tablecloth folds." Wind deformation of microbial mats would now appear to be a critical additional consideration in interpreting ancient stromatolites.

At $\$ 98$ (US) this somewhat disjointed, but readable and convenient compilation of interdisciplinary studies is rather expensive. It will appeal to libraries, but it is outside the price range of most individual academies with an interest in this topic. This is unfortunate as it is the first attempt at a rigorous, scientific multidisciplinary analysis of an otherwise much overworked paleoecological theme.

S.T. Newcombe, M.W. Stirling and J.A.E.B. Hubbard London, U.K.

TRACE ELEMENTS IN THE TERRESTRIAL ENVIRONMENT

\section{D.C. Adriano}

Springer-Verlag, 533p., 99 illustrations, 1985, \$75 (US)

This volume is supposed to fill a perceived need for "a comprehensive reference book on many aspects of trace elements in the land environment." A large volume of literature now exists on the distribution and fate of individual trace elements in soils and plants. Any attempt to present an overview of the massive information in a few printed pages is bound to be highly selective. What some may consider to be key topics are left out and major themes receive only cursory treatment. Trace Elements in the Terrestrial Environment entails such a flaw and is probably not the definitive (and desirable) work on the important topic.

The first chapter in the book gives an overview of the general sources, retention and functions of trace elements in soils and plants. This is followed by chapters on individual elements arranged alphabetically. The elements covered are arsenic, boron, cadmium, chromium, copper, manganese, mercury, molybdenum, nickel, selenium, and zinc. Each chapter includes the economic importance of the particular element, its requirement by and detriment to plants, its health limits in drinking water and food, and its origin in the environment. For some inexplicable reasons, the basic soil terminology is defined in the chapter on zinc rather than with the introductory material of the first chapter. The final chapter on "other trace elements" contains cryptic discussions on antimony, barium, beryllium, cobalt, fluorine, silver, thalium, tin, titanium, and vanadium. A short Appendix provides the scientific names of plants and organisms, and a glossary of selected soil terms. 
Although several related books and monographs have been published on the topic, the volume under review is one of the few that have endeavored to provide an integrated discussion of the sources, occurrence, behavior and biogeochemical cycling of trace elements in the terrestrial environment. It provides a readable discussion of the most important aspects of trace elements in the agricultural and natural ecosystems with emphasis on applications rather than theory. As a reference material, Trace Elements in the Terrestrial Environment should be on the shelf of every library that eaters to the needs of soil and/or environmental scientists.

J.O. Nriagu

Burlington, Ontario

\section{THE MINERAL AND ROCK RESOURCES OF GHANA}

\section{G.O. Kesse}

A.A. Balkema, Rotterdam, 1985, 610p., $\$ 50$ (US)

Ghana's economic and political troubles have been more newsworthy over the past quarter century than its mineral wealth. But the country that was called the Gold Coast before independence is a place with a fascinating geological setting, a rich past and a yet richer potential as a mineral producer. This is the country with an area approximately $1 \%$ of that of the U.S.S.R., that during the 16 th century produced an estimated $35 \%$ of the world's gold, and which 25 years ago produced almost a million ounces of gold per year, ranking only behind South Africa, the U.S.S.R., and the U.S.A. in world production. During the first half of this century, Ghana averaged one ounce of gold per ton of ore mined, and some mines currently survive on one tenth of this ore grade.

Until recently Ghana produced up to three million carats of diamonds per year, fourth in the world production behind Zaire, the U.S.S.R., and South Africa. It has mined manganese ore so high in quality that it has been put directly into dry cells with no processing except for grinding. This is also the country that has been attempting to implement a new metallurgical process that uses indigenous lateritic iron ore, limestone, charcoal, silica sand, ferromanganese, caustic soda and hydroelectricity to produce at one plant (near Takoradi, located within $125 \mathrm{~km}$ of all of these raw materials) steel, alumina, cement, commercial charcoal, lime, and fertilizers!

The author, G.O. Kesse, does not elaborate on the economic and political troubles of his country, but he does put them into perspective, so that the informed reader can assess the role played by recent events on the state of Ghana's mineral industry. Kesse's purpose is to compile the voluminous but little known records of the Ghana Geological Survey into a reference work on the country's mineral resources, to review the current status of development of these resources and to suggest areas for future exploration and development. For discussions of the more controversial aspects of regional geology and metallogeny, the reader must turn, for example, to J.B. Wright and others on the Geology and Mineral Resources of West Africa (Allen \& Unwin, 1985), J. Fabre's Stratigraphic Lexicon for West Africa (Pergamon, 1983), and the major references cited by Kesse.

As the Director of the Geological Survey for the past 13 years, Kesse is well qualified to write this book. In the mid1970 's he prepared a number of Survey summary reports on individual commodities such as manganese, limestone, and clays. This book is largely a compilation and expansion of that effort, now published for a wider audience.

Following a brief introductory sketch of the importance of minerals, the book presents background sketches on Ghana and its mineral resources, and detailed chapters on metallic and non-metallic minerals, bulk construction materials, radioactive and economically minor minerals, minerals in concentrates, and hydrocarbons. Kesse also gives a brief description of the history and functions of the Ghana Geological Survey, summary tables of mineral and rock resources, and a description of legislation affecting national mineral resource development.

Each commodity is discussed with an introduction, description of its uses, occurrences in Ghana (history of exploration and development, geology, analysis of ores, assessment of future potential), and references. Gold, manganese, diamonds, bauxite, clays, hydrocarbons, iron, uranium, and limestone dominate the discussions of mineral commodities. This is not surprising in light of the country's mineral production history and its desire for added discoveries. There is a subject, but no author index, and each chapter contains its own list of citations.

The high grade and relatively easy extraction of Ghana's gold from the ore are legendary among specialists. Not so well known are the closures of several mines for reasons such as temporary economic conditions, poor management, or transport difficulties. Moreover, few know of the numerous prospects that were considered rich enough to develop when they were discovered around the turn of the century, but which at that time were too remote to be successful. Kesse covers these occurrences in some detail, as he does for those of manganese, diamonds, and bauxite, also currently being produced, and all with prospects of varying promise that are discussed in this book.

Clays are abundant in all regions of Ghana and have been used in making pottery, industrial ceramics, bricks, tile, and paints. Iron was mined prehistorically and has some potential for future mining under favorable economic conditions. Uranium and hydrocarbons have received a great deal of attention, with only a very modest oil production as a current benefit. Known limestone resources are spotty but may be sufficient to support the proposed integrated iron and steel project mentioned earlier.

Kesse discusses the future potential of many of Ghana's commodities, and his message is that the potential for development is widespread. He does not, however, explain that most prospects have languished so long because of perceptions - some right, some wrong - of the country's investment climate, that they have not been investigated with modern methods of integrated exploration.

The book is addressed both to Ghanaians and outside readers. The former, who may not have access to many recent books on economic geology, are provided with general background information on the uses of individual mineral commodities that the reader outside Ghana can find discussed more completely elsewhere. The local reader will be comfortable with the level of sophistication of geographical references and the use of the volatile local currency, whereas the foreigner may be overwhelmed in places by these references. The outsider, on the other hand, 
is provided with background sketches of recent political and economic events and of mining codes that the local reader may wish to skip. Kesse handles the necessary compromises well, though more maps would have helped to orient geographically the outside reader, and references to local currency should have been supplemented with equivalents in a more stable, internationally recognized funds.

Many findings after the mid-1970's have been omitted. For example, there is no description of the recently discovered Adum Banso rutile-magnetite deposit, which might contain over $10^{9}$ tons grading from high rutile to high magnetite and located $11 \mathrm{~km}$ from the port of Takoradi. Some new findings in geology and metallogenesis have been left out, as are interesting occurrences in similar settings in neighbouring countries such as a newly discovered massive sulphide deposit in a Birimian setting in Upper Volta. Promising exploration techniques for many commodities have also been omitted from Kesse's discussions.

The coins used for scale reference in some figures are of different denominations and sizes, but this is not noted in the text. The publisher's editing of the camera-ready typescript is patchy; there are several typographical errors, misplaced illustrations, and one missing figure. Kesse could also have provided a valuable service by guiding those interested to the wealth of unpublished information that is housed in the Geological Survey and elsewhere in Ghana.

However, one cannot expect this one book to make up the ground that has been lost for 25-50 years in reporting on Ghana's geology and mineral resources. If you are interested in mineral resources development, this is a book worth having. With luck, it will stimulate other writers to produce more on this fascinating, underdocumented area.

David A. Hastings Boulder, Colorado

\section{GEOLOGY AND RADW ASTE}

\section{A.G. Milnes}

Academic Press Inc. (London) Ltd., 328p., 1985, (H) $\$ 60.00$, (P) $\$ 39.95$ (US)

\section{GEOENVIRONMENT AND WASTE DISPOSAL}

\section{K. Cidlinsky (ed.)}

Unesco, Paris, and UNEP, Nairobi, 296p., 1985. No price listed.

The volumes of materials used and moved by man exceed annually those involved in ocean crust formation, erosion (flow through the sedimentary cycle), and mountain building. Man has now become the most important agent modifying our planet. Natural systems once thought to have infinite buffering capacities for our wastes and actions are breaking down; the primary solution to pollution is no longer seen as dilution.

The works of man and large-volume, "non-toxic" wastes disturb the sedimentary cycle, water quality and the stability of land masses. Toxic and low-level radioactive wastes require safe disposal for several hundred years, and high-level radwastes require safe storage measured in hundreds of thousands of years. The latter have the added complication that the peak of toxicity develops several hundred years after burial. The global anthropogenic load on nature is changing geological properties and creating an unpredictable and variable environment.
As Milnes aptly states (p. xiii), "Scientists, politicians and the public at large are demanding answers to questions which have hardly been asked before, or only been accorded passing academic interest. The inability of geologists to provide quick, assured solutions, and the patent lack of consensus among earth scientists on many points, has stimulated interest in wide eircles, a desire to know more about how the Earth works, why this knowledge is important for the problem at hand, and why so many uncertainties still remain."

Geology and Radwaste outlines succinctly and fully the background to radioactive wastes and their disposal. It details the sources and properties, time perspectives, and disposal options and practices for various waste forms. The author indicates that the purpose of multi-barrier disposal systems in engineered underground sites is to ensure extremely low dispersal rates in circulating underground waters. Most countries are searching for the best underground sites - not necessarily the best rock-type - within their boundaries, and their research seeks to develop methods that will permit description of the total geoenvironment.

The mainstay of Milnes' book lays out "the contribution of the earth sciences to an understanding of long-term performances of any radwaste isolation system" (p. 53). It reviews geological time, the structure and evolution of the crust and biogeochemical and sedimentological surface processes. Three chapters are devoted to the formation and properties of sedimentary rocks, volcanic processes and products, and natural and synthetic (ceramic) crystalline rocks. The latter chapter exemplifies the tight integration and balance in which Milnes links geological processes with physical and chemical barriers being developed for the encapsulation of radwastes.

The author reviews the near- and far-field effects that temperature, pressure, fluid flow and geochemical rockfluid waste can have on repository sites. Examples of natural analogues demonstrating chemical processes of elemental mobility in nature that may be applicable to engineered systems include the hydrothermal activity, structure and fracture filling history of the Eye-Dashwa Lakes granite of Ontario and the St. Austell granite, U.K., the hydrothermal gold deposits of the Negus Mine, Canada, the saline deep waters of the Canadian Shield, the natural nuclear reactor system of Oklo, Gabon and the salt diapirs of Oakwood, Texas, and Garleben, West Germany.

Milnes also reviews the physics and chemistry of oceans and of the types of deep-sea sediments in order to assess "the (past) practices of releasing wastes to the ocean waters . ." (p. 54). The last chapter in this main section addresses the impact future continental glaciation may have on the long-term stability of radwaste repositories.

The final part of the book deals with predictive geoscience and the selection of repository sites using geological data to establish the probability of long-term safety. Milnes notes astutely that although scientifically it is possible to determine the safest possible disposal system that guarantees any dose to man will not exceed regulatory limits, convincing proof of safety is part and parcel of the political process rather than science alone.

Geology and Radwaste is written thoughtfully and is thoroughly researched, well documented and contains lists of selected literature and an author and subject index. The use of simple language and numerous classical geological examples and processes is welcome.

Though Milnes writes outside his speciality and though he is not convinced that the "nuclear road" to limitless, cheap energy is the right one, he provides a comprehensive, 
objective view of both the facts and the role that geoscience must undertake for the safe disposal of wastes already at hand. Any scientist who wishes to form opinions on the disposal of wastes and, in particular, radwastes must read this book.

Geoenvironment and Waste Disposal is an exceptionally welledited collection of scientific papers presented at an Interdisciplinary Expert Meeting in Vienna in 1983. The topic is part of a Unesco project on the "Protection of the Lithosphere as a Component of the Environment," and the meeting was also sponsored by the International Atomic Energy Agency. The book develops the idea that "the rational use and protection of the geoenvironment requires a full understanding of the complexity of the environmental system, of the relationships between the lithosphere, the hydrosphere, the atmosphere and the biosphere, and of the influence of Man's activities on each of these" (p. 8).

This thesis is developed by I. Snezhko who notes that, "When the anthropogenic pressure on the geoenvironment was at a low level, planners and scientists were able to make relatively accurate forecasts of the geoenvironmental change caused by the use of land and natural resources" (p. 39). Now society has loaded nature to create "an unpredictable and variable geoenvironment in which, very often, geological properties have changed" (ibid).

G. Vartanyan sees subsurface waters as the dynamic portion of the geosphere, and he provides an excellent and comprehensive tabulation of "Nuclear-physical and isotope methods of studying the problem of geological environmental protection." A treasure trove of statistics by B. Moldan is concerned with natural and man-made global geochemical fluxes and should be read by all scientists. The anthropogenic sediment "demandite" that accumulates at the rate of $2 \times 10^{16} \mathrm{~g} /$ year is two or three times greater than the flow of matter through the sedimentary cycle, and from mining alone the flow is $3.3 \times 10^{16} \mathrm{~g} /$ year.

In comparing the accelerating rates of erosion due to human activity in the Yangtze and Yellow River drainage systems, $\mathrm{N}-\mathrm{H}$. Tang notes that deforestation, land deformation due to mining, and groundwater pollution due to waste disposal are the cause. In a review of geoenvironmental parameters from the point of view of water management, G. Kovacs notes that subsurface waters exceed $20 \%$ of Earth's total fresh water, constituting a "non-separable part of the crust" (p. 150).

According to B. Foxworthy "the trends in groundwater dependency and waste-disposal impacts are clearly on a collision course" (p. 153). He quotes examples from the U.S.A., including Long Island, N.Y., and the San Joaquin Valley of California to dispell the common assumptions that burial is an effective way of keeping wastes out of the "realm of human concern," and that the substrate "will somehow render the waste products harmless through decay, filtering, and dilution" (p. 163). Damage to the aquifer in some instances is chemically and structurally irreversible.

In a review of a mathematical treatment of geochemical reactions and biochemical and physical processes, G. Matthess demonstrates the effects of point and non-point, diffuse sources of contamination. He concludes that waste should be recycled and reused as much as possible. M. Arnould's paper on geoenvironmental mapping is an excellent list of what such maps should contain in areas of intense land use. He points out that $99.99 \%$ of Earth's land surface comprises unconsolidated deposits, which are commonly not mapped as well as are outerops.

In the final section, M. Langer, F. Marcus and F. Gera deal with waste disposal and environmental protection in a similar fashion to Milnes. The concept of underground disposal includes a multiple-barrier system that controls dispersal and possible release to the biosphere at rates many times lower than natural background levels. However, highly radioactive wastes have long-lived toxicity, and their predictable long-term behaviour and effect on the geosphere are not well known. Methods for disposal of high-level radwastes should include prolonged interim storage to reduce the thermal load to the repository.

The Unesco-UNEP book is for georesource managers at all levels of scientific, technical or political responsibility. It is both conceptual and practical and can be used to design long-term approaches to ameliorate societal impact on the geoenvironment. In both this and Milnes' book the totality of the geoenvironment is stressed. To ignore the interrelationships of its components could result in an inestimable reduction of resources available for the future. Both books are written for wide readerships. They make fascinating reading and are highly recommended for anyone with even a minimal interest or training in science or engineering.

I. Ermanovies Ottawa, Canada

\section{STILLWATER COMPLEX}

Gerald K. Czamanske and Michael L. Zientek (eds.)

Montana Bureau of Mines and Geology Special Publication 92 , Butte, 1985 , $\$ 28$ (US)

Layered igneous rocks have fascinated petrologists for decades, and studies of the Skaergaard intrusion in Greenland, the Rhum Complex in Scotland and the Stillwater Complex in the United States perhaps more than any others shaped the early understanding of layered rocks. Apart from its purely scientific importance, the Stillwater is also of great economic significance. The Ultramafic Series of the Complex is the repository of about $80 \%$ of United States chromite resources, and sub-

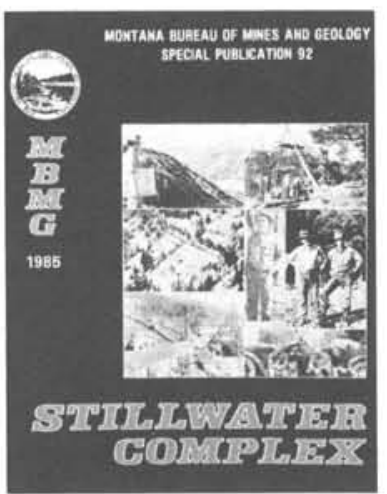
stantial low grade nickel-copper sulphide resources occur in the Basal Series. The focus of current exploration interest, however, is on deposits of the platinum group element in the Banded Series. These will quite likely make the Complex the first major primary source of platinum group element in the Western Hemisphere. The continuing scientific and economic interest in the Stillwater Complex make the volume published recently by the Montana Bureau of Mines and Geology a timely and welcome addition to the literature. 


\section{Book Reviews}

This book contains 28 contributions by 37 authors who represent most of the research and mineral exploration groups active in the Stillwater in recent years. The first third of the volume provides a summary of the geological setting, geophysical and geochemical characteristics, and economic geology of the Complex and its immediate host rocks. The remainder presents detailed geological descriptions of specific areas progressing along strike from east to west. There is also a comprehensive bibliography of Stillwater geology.

The contributions emphasize observational field and laboratory data, and interpretations are generally limited to those firmly based in fact. There is little in the way of genetic models of the "arm waving" variety. The volume is profusely illustrated with more than 330 maps, diagrams and photographs, the majority of which have not been published previously. Many readers will be particularly interested in the descriptions of the J-M Reef platinum group deposit, which has been widely compared with the Merensky Reef of the Bushveld Complex, currently the world's most important source of platinum. Although the similarities are striking, the J-M Reef appears to be much more variable along strike than the Merensky.

Many of those who have followed the Stillwater literature over the years have been confused by the proliferation of stratigraphic nomenclature. For example, there have been in the past at least 15 stratigraphic schemes used for the lower part of the Complex and at least 7 for the upper part. The editors are to be commended for endeavoring to enforce a degree of uniformity among the many contributions, and it is to be hoped that their suggested stratigraphic terminology will carry over into future work.

The publication seems to have succeeded admirably in achieving its stated objective, which is "to provide an opportunity for geologists to learn much about Stillwater Complex geology by self-guided study of outerops and rock sequences in the field." The degree of detail in the road logs and traverse descriptions should ensure that the geological tourist will have little difficulty in locating exposures. The large size of the book makes it somewhat inconvenient to carry in the field, but this is a small price to pay for the wealth of information it contains. Indeed, this volume goes far beyond what is normally expected in a field guide, and the fact that it makes available so much new data means that it will be a widely cited primary reference.

The book contains much of historical as well as scientific interest. There are numerous period photographs of the geologists, prospectors and engineers who earried out the first exploration and development at Stillwater, and of the early settlements and mining operations. The chapter on exploration history draws attention to an interesting and perhaps ironic fact The presence of platinum group minerals in what is now called the Banded Series of the Complex and the similarity with the Merensky Reef of the Bushveld Complex was reported in publication by A.L. Howland, J.W. Peoples and E. Sampson in 1936. However, this revelation generated little exploration for platinum until the 1960 's, and it was not until 1973 that the J-M Reef was finally discovered by geologists with the Johns-Manville Corporation.

This remarkable publication will be indispensable for visiting the Stillwater, but it is also recommended highly to igneous petrologists and particularly to those interested in layered intrusions. It should also find a wide audience among explorationists and mineral deposit geologists, given the current interest in the platinum group elements.

J.M. Duke Ottawa, Canada
NEW from SWIFT (UK) MODEL "F" H/I AUTOMATIC POINT COUNTER

is a considerable advance over previous models. Now, with 12 channels -- one isolatable from total: Employs microprocessor for compactness, optimum reliability and extra facilities .such as percentage key and up to 9x interval multiplier: Separate LED displays for channels, and for total plus combined 4-digit preset -- with audible signal.

Point counting is not limited to polarizing microscopes.

Attachments for all well-known microscopes.

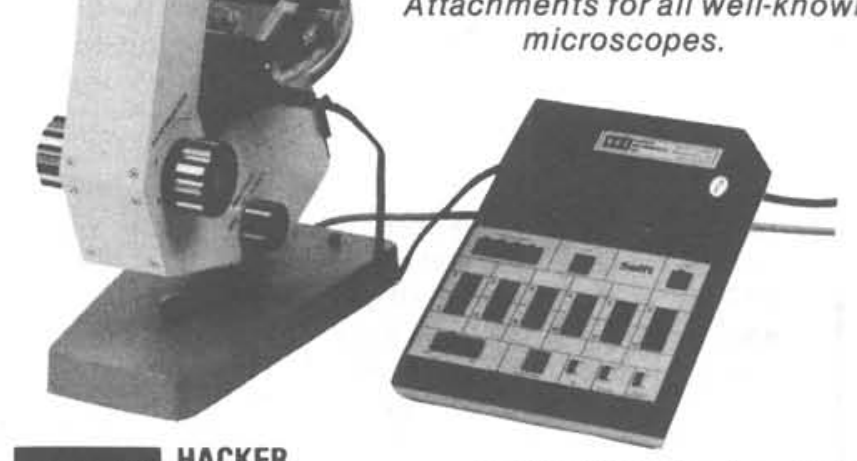

HACKER
INSTRUMENTS
INC.

Box 657, Fairfield, New Jersey 07007

(201) 226-8450

\section{प? \\ Recent titles}

(in addition to the semestrial "Bulletin")

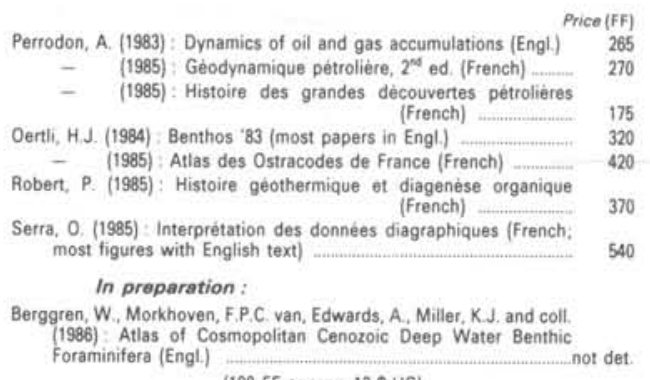

(100 FF approx. 12 \$ US)

Send to

Elf Aquitaine-Edition 64018 Pau/FRANCE

Order Form

Address

Send :

$\square$ Catalogue Elf Aquitaine Publications

$\square$ Payment enclosed $\square$ Please bill me

$\square$ Charge my credit card $\square$ Visa $\square$ MasterCard $\square$ Am. Express $\square$ Diners

Account No Expires:

Signature : Date : 
A review of volcanic-sedimentary sequences of the Superior and Slave Provinces and their mineral deposits. Archean crustal development and Proterozoic reworking, plus papers on the Archean of Australia and South Africa. Includes a coloured lithostratigraphic map (1:500,000) of the Abitibi greenstone belt.

380 p., 1985

$\$ 35$ Cdn. (GAC Members) $\$ 42$ Cdn. (Non-Members)

ORDER FROM: GAC Publications, Business and Economic Service Ltd., 111 Peter Street, Suite 509, Toronto, Ontario, Canada, M5V $2 \mathrm{HI}$

ADD: $\$ 3$ (Canadian) postage (BOOK RATE) and handling for each publication ordered. Payment must accompany orders. Make cheque payable to Geological Association of Canada. If paying by VISA or MASTERCARD give full card number, expiry date and signature.

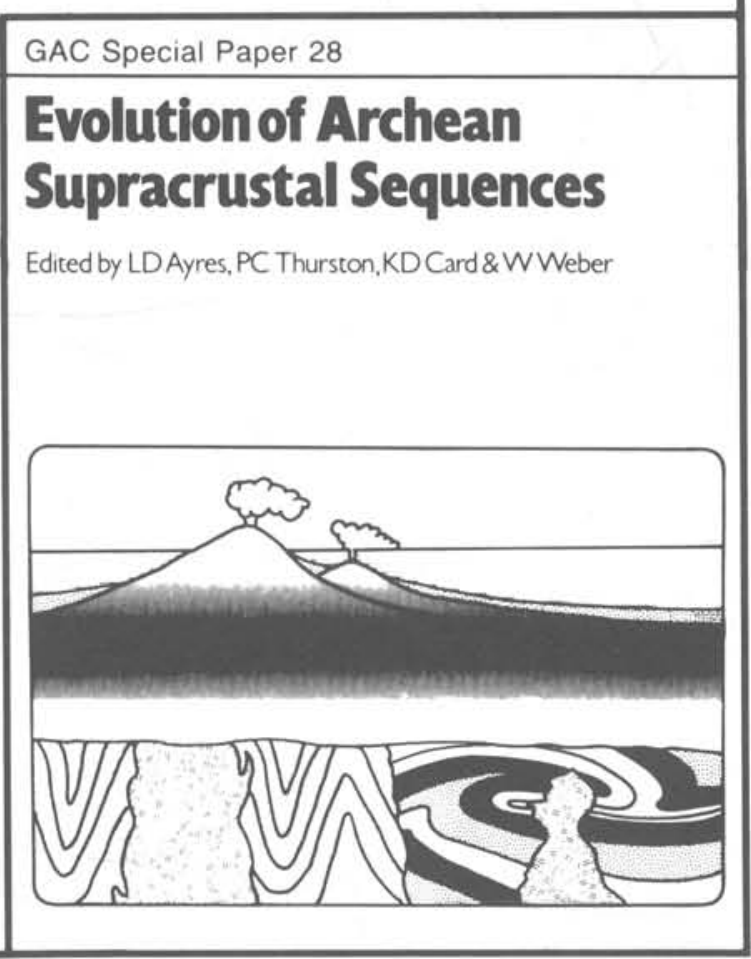

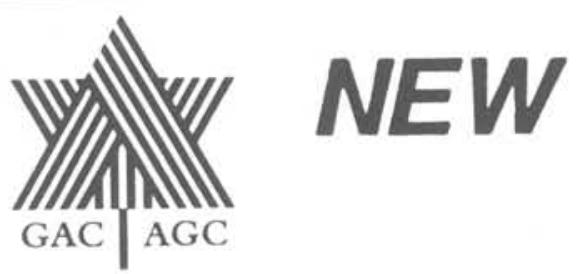

A synthesis of the voluminous unpublished material on one of the best uranium deposits in North America. Reviews the geology. mineralogy, geochronology, geochemistry, stratigraphy, geophysics and metallogeny of this conspicuous ring-type structure. Includes a coloured map (1:50 000) - Bedrock Geology of the Carswell Structure.

230 pages, 1985.

$\$ 35$ Cdn. (GAC Members) $\$ 42 \mathrm{Cdn}$. (Non-Members)

ORDER FROM: GAC Publications, Business and Economic Service Ltd., 111 Peter Street, Suite 509, Toronto, Ontario, Canada, M5V $2 \mathrm{HI}$

ADD: \$3 (Canadian) postage (BOOK RATE) and handling for each publication ordered. Payment must accompany orders. Make cheque payable to Geological Association of Canada. If paying by VISA or MASTERCARD give full card number, expiry date and signature.
GEOLOGICAL ASSOCIATION OF CANADA

GAC Special Paper 29

\section{The Carswell Structure Uranium Deposits, Saskatchewan}

Edited by R Lainé, DAlonso and M Svab

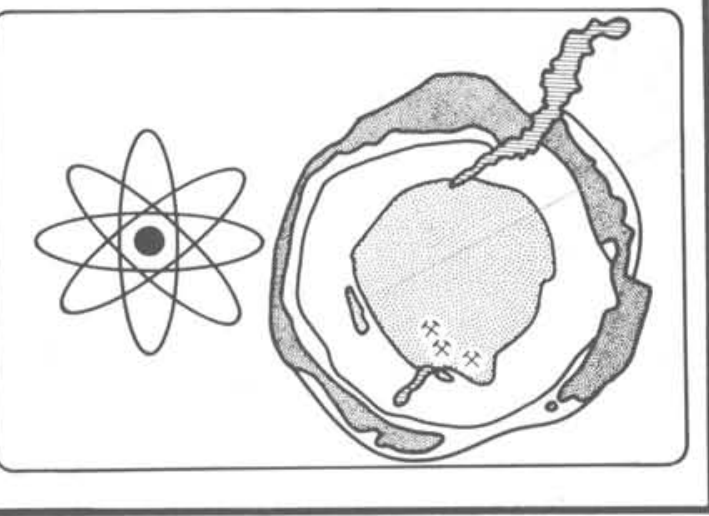

